DOI $10.14746 /$ ssp.2014.3.10

Jędrzej SKRZYPCZAK

Adam Mickiewicz University in Poznań, Poland

\title{
International Standard Serial Number (ISSN)
}

Press publications, both printed and electronic, generally bear the international standard serial number (ISSN). The need for such a universal identification code for this type of publications follows from the necessity to ensure certainty about their turnover and exchange between publishers, distributors, libraries and archives. The subject of this paper is the analysis of the role and significance of the ISSN code as well as the international and domestic principles of assigning it.

It should be mentioned at the beginning that in 1967, the United Nations Educational, Scientific and Cultural Organization (UNESCO) alongside the International Council for Science (ICSU) began work to establish the United Nations International Scientific Information System (Guidelines for ISDS, 1973, p. 3). Working within its framework, in April 1970, the Working Group on Bibliographic Descriptions published the Report on the Feasibility of an International Series Data System and Preliminary System Design, calling for an international system for coding serial publications to be established (Report, 1970, p. 3). In the meantime, the idea of the ISSN standard was developed as part of work on the ISO/TC 46 to provide a unique number to identify serial publications (Santiago, 1973, p. 41). It should be explained here that the International Organization for Standardization is the international federation of national institutions in charge of developing the applicable standards in their respective countries. It features ISO technical committees, which draw up regulations for various standards.

On 6 November, 1973, the Director-General of UNESCO (CL 2245), with reference to Resolution no 2141, announced that the standardisation organisation would be located in Paris, in conformity with the agreement signed between UNESCO and France. The International Series Data System (ISDS) was set in operation in the same year (Santiago, 1993, p. 41). Its tasks involved the supervision of the assignment of the ISSN numbers, defining identification codes, propagating information about the system and developing the network for information exchange between the entities 
involved (UNESCO, 1973, p. 1-3). A two-tier system of entities was set up to manage the data that identifies serial publications. Tier one is the International Centre, seated in Paris, operating within the French National Library, whereas tier two consists of national and regional centres. The ISDS network was officially established in 1975, followed one year later by the above-mentioned ISSN International Centre in Paris. The ISDS later became the ISSN. At present, the ISSN network consists of eighty-eight states (List of the Member Countries).

By virtue of the Law of 27 June, 1997, Article 17, section 1, item 5 on libraries (Ustawa, 1997), the International Standard Serial Number is assigned in Poland by the National Library (Biblioteka Narodowa) in Warsaw, or, to be more precise, by the ISSN National Centre. Initially, the code was assigned according to the principles of the Polish Standard (Polska Norma) PN-76/N-01207, later replaced by PN-ISO 3297:2001 and, currently, by PN-ISO 3297:2010 (Polska Norma, 2010, p. 2-3). It implements the currently binding English version of the International Standard ISO 3297:2007, which replaced its predecessor, ISO 3297:1998. The main change involved the adaptation of the standard to a digitalised environment. A principle was adopted of assigning different media offering a given continuing resource different ISSN codes. It should be mentioned here that the International Standards are designed by technical committees operating in a given area, and later consulted with member organisations. To be approved, the International Standards need to be accepted by at least $75 \%$ of national organisations involved in the consultation procedure. The ISO 3297 standard was developed by the ISO/TG/46 technical committee, Information and Documentation, SC 9 Subcommittee, Identification and Description of Information Resources. The Polish Standard, which is a literal translation of the international document, was drawn up by the team KT 242 for Information and Documentation, and approved by the President of the Polish Committee for Standardisation on 28 December, 2009 (Polska Norma, 2010, p. 4).

This document contains the definitions of terms that are of crucial importance for the issue discussed in this paper. The terms applied in this standard are different from those defined by the Law on the press. For instance, in conformity with item 2.1 a "continuous resource" (zasób ciagly) ${ }^{1}$ is

Terminology applied herein conforms to that established by the National Library (Słownik terminologiczny z zakresu bibliografii i katalogowania - http://sternik.bn.org.pl/vocab/index.php) (translator's note). 
"a publicly accessible publication on any medium, published successively without a predetermined end" (Polska Norma, 2010, p. 6). It is additionally explained that "[s]uch a publication is usually published in successive or updated sets, usually coded numerically and/or chronologically. Continuous resources include such serial publications as newspapers, periodicals, journals, magazines, etc. and integrating resources such as ongoing updated loose-leaf publications and ongoing updated websites" (Polska Norma, 2010, p. 6). The term "serial publication" (wydawnictwo ciagte) is defined as "a continuous resource published in successive, separate sets or parts, usually bearing numerical designations without a predetermined end" (Polska Norma, 2010, p. 6). They are exemplified by "[j] magazines, electronic journals, updated rosters, annual reports, newspapers, book series, as well as those journals, magazines and newsletters issued over a specific, limited period of time, which otherwise bear all the characteristics of serial publications (e.g. a newsletter associated with the event)." The same document defines an "integrating resource" (zasób aktualizowany) as "a continuing resource complemented or altered by means of updates which do not constitute separate parts and are integrated in the resource." The Polish Standard exemplifies this by "databases, websites and loose-leaf publications updated without a predetermined end" (Polska Norma, 2010, p. 7). Item 2.6 of the Polish Standard applies the term "key title" (tytut kluczowy) which is understood as a "unique name of a continuous resource, designated by the ISSN network and inextricably linked with its ISSN number" (Polska Norma, 2010, p. 7). It also features a comment that "the key title can be identical with the title of the resource or, in order to ensure unambiguity, it can be construed by adding identifying or describing elements, such as the name of the issuing body, place of publication, designation of an edition, etc." (Polska Norma, 2010, p. 8). Finally, the ISSN-L, or linking ISSN, is "the ISSN designated by the ISSN network in order to enable the collocation and links between different media of a continuous resource" (Polska Norma, 2010, p. 7). Item 7 stipulates that "the linking ISSN should be designated from the ISSN numbers assigned to a given continuous resource on different media" (Polska Norma, 2010, p. 9).

It should also be stressed that, in conformity with item 4.4 of the same document, each ISSN number is required to be permanently assigned to the key title attributed to the publication at the time of its registration (Polska Norma, 2010, p. 6). This provision does not mean that the institution that assigns the ISSN number determines the title of the publication, 
as this is the sole competence of the publisher. Since 1 January, 2003, by virtue of the provisions of Article 5, section 3 of the Law of 12 September, 2002 on standardisation (Ustawa, 2002) the application of the Polish Standard is voluntary in Poland. The literature on the subject features a single opinion that the ISSN "signifies that a given publisher is authorised to conduct publishing activities" (Dobosz, 2006, p. 99). This approach is unjustified, though, since the issue of the permit to conduct press activities is determined by being entered on the register of newspapers and journals, while the ISSN is related only to the assignment of a code identifying a given publication. The issue of obtaining a permit to publish a periodical is related to the decision of the court that conducts the register of newspapers and periodicals, rather than the ISSN being assigned. The legal definition of "the press" is stipulated in Article 7, section 2, item 1 of the Law of 26 January 1984 on the press (Ustawa ${ }_{2}$ 1984) saying that it is understood as "periodical publications which do not form a closed, homogeneous entity, appearing at least once a year, bearing a permanent title or name, the current number and date, in particular: newspapers and journals" (Ustawa, 1984). It follows from the above that the necessary prerequisites for press publications are their periodical character, openness and diversity of content, determined frequency of publications (at least once a year) and a permanent title, current number and date (Dobosz, 2006, p. 75; Skrzypczak, 2011, p. 191; Zaremba, 2007, p. 27). By virtue of Article 7 , section 2 , item 2 a daily is a printed periodical publication, or a message conveyed by means of sound, or sound combined with picture, providing general information and published more often than once a week. By virtue of Article 7, section 2, item 3, a journal is defined as a printed periodical publication published not more than once a week and not less than once a year. Therefore, the frequency with which a periodical publication is published is a conclusive criterion allowing it to be qualified as a daily or a journal. The criterion of the frequency of publication makes it possible to distinguish dailies, weeklies, bi-weeklies, monthlies, quarterlies, semi-yearbooks and yearbooks. In conformity with Article 20, section 1 of the Law on the press, it is obligatory to be registered to publish a daily or a journal. The competent authority in this respect is the regional court having jurisdiction over the publisher's seat. Registration bears certain legal consequences. Firstly, the opinion of the Supreme Court expressed on 24 October, 2002 (Postanowienie SN, 2002), should be referred to here, explaining the nature of the registrations system for the press. It is stated that the system of registration of press titles is more than a system of mere 
notification, since the registering court is obliged to take into account both the interest of the publisher and that of the readers; by this token registration encompasses a certain controlling aspect without infringing on the principle of the freedom of press. In the opinion of the Supreme Court, presented in the substantiation, taking into account the possibility of infringing on the right to protect the name of an existing press title is primarily concerned with the publisher's interest. It is intended to protect him against unfair competition which may try to take advantage of the renown of the existing press title and try to impersonate it with their own publication bearing a very similar title, or a "convergent" (zbieżny) title, as stipulated in the Regulation of the Minister of Justice of 9 July, 1990, concerning the register of dailies and journals (Rozporządzenie, 1990). The protective function of Article 21 of the Law on the press is not limited to the above. It also encompasses potential buyers, preventing them from being misled as to the actual identity of the magazine they are purchasing. Therefore, the above-mentioned regulation protects the existing title, both on behalf of its publisher and readers, enabling them to select and buy the title they are actually seeking. Given these legal circumstances it has to be agreed that the "institution of registration [as such] does not provide effective and comprehensive protection to the press title. The rights following from registration are formal in nature and they are provided not by the legal relation but by the mere fact of registration, which constitutes the foundation and reason for granting a given entity the capacity for certain conduct. Given this formal nature of the registration procedure of a press title, it is irrelevant for the assessment of the unlawfulness of activities taken in relation to its name when this name infringes on the third person's legal rights to the company [title]" (Sobczak, 2008, p. 693). It follows from the above that in the opinion of the judicature, the registration of a daily or journal does not produce a new defined legal right. This attitude is also fully supported by legal doctrine. There is a well-established and uncontested position in this respect that "the registration procedure is formal in character and the role of the registration court is limited. This procedure does not prejudge the right to the press title" (Sobczak 2008, p. 696).

The Polish Standard stipulates that the ISSN code comprises eight digits and a specified country code. The last digit is a control character that can be replaced by the letter "X." The standard explains that "this digit is calculated on the basis of the modulus 11 using the weighting factors 8 to 2, with $\mathrm{X}$ used to substitute for 10, if 10 is the check character (Polska Norma, 2010, p. 8). The Polish Standard stipulates in detail that the ISSN 
code should be presented as two sets of four digits, separated by a hyphen, and always preceded by the ISSN acronym and a space (the Polish Standard quotes the following examples: ISSN 0251-147, ISSN 1050-124X).

It is also stressed that each issue of the journal under the same title should bear the same number (Nowińska, 2008, p. 111). In conformity with this standardisation document, the ISSN code should be placed in a conspicuous position, on the first page of or inside the first signature. Item 7.2 of the same document specifies that the ISSN code should be printed "in a conspicuous place in successive signatures of printed continuing resources, in the following order of preference: the first page of the cover, title page, header, masthead, the last page of the cover, colophon and publisher page." If possible, the ISSN code is customarily placed in the upper right corner of the first page of the cover (Sobczak, 2008, p. 726).

According to the standard in question, the ISSN code is assigned at the publisher's request. Therefore, it is impossible for a code to be assigned ex officio. In conformity with the guidelines developed by the National Library, "the publisher who wants his serial publication to be assigned the ISSN code should send the application for the ISSN code and other relevant materials by mail to the ISSN National Centre" (Informacja Biblioteki Narodowej, 2014). The guidelines by the National Library indicate that the application should state the title, former title(s), publisher's name and address, the frequency of publication or its updating, physical presentation (print, CD-ROM, multimedia, online, other), the date of the first issue (signature, volume, etc.), language(s) of publication and abstracts, the title of the main publication (in the case of addenda) and the electronic address (in the case of online publications - contact person, telephone, email). It can be seen from the above that publications are assumed to be published in different language versions while bearing the same ISSN code (Informacja Biblioteki Narodowej, 2014).

In the light of the above provision, as well as in the opinion of some representatives of the law, a publisher is not obliged to apply for an ISSN code to be assigned (Kosmus, Kuczyński, 2011, p. 348). The same conclusion can be drawn from the information available from the body assigning the ISSN codes. It is stated that when applying for the code to be assigned "in the case a given title is already being published, two pieces of every issue (sets, volumes, yearbooks) that has already been published should be sent to the ISSN National Centre" (Informacja Biblioteki Narodowej, 2014). It is therefore assumed that at least the first issue will be published 
without the code, although the National Library provides for the first issue to be assigned a code. In such an instance, a photocopy of the final version of the title page and publisher page designed for the first issue should be submitted. The possibility of publishing a daily or a journal without the relevant code raises certain legal doubts (Sobczak, 2008, p. 726). It appears, however, that the ISSN National Centre also allows for such a situation. The guidelines by the National Library contain a remark that if the title is published without the relevant code, and the publisher intends to obtain the ISSN, he should submit two pieces of every issue that has already been published to the ISSN National Centre.

The guidelines of the National Library state that the application for the ISSN code to be assigned to a journal published only online should be accompanied by the printouts of the screenshots of the homepage, the title page of the first issue and of the current issue as well as the pages with the details of the publisher and editor. It is also unambiguously determined that it is impossible to assign an ISSN code for an online magazine that has not been published yet (Informacja Biblioteki Narodowej, 2014). The National Library makes a similar restriction as regards websites. This may be surprising, however, as it is explained that the regulation concerns academic websites "displaying the formal features of 'continuity', such as the dates accompanying individual papers, the date of the latest update or the current date next to the title" (Informacja Biblioteki Narodowej, 2014).

The guidelines developed by the National Library state that the heads of ISSN National Centres have agreed that an ISSN code cannot be assigned to (a) websites of companies, institutions, organisations, associations and so on; (b) local or ephemeral websites, advertising and promotional websites; (c) websites; (d) private (personal) websites; (e) websites featuring only commercials and links; (f) blogs; (g) websites without editorial content; (h) websites without a clearly determined title of the resource (Informacja Biblioteki Narodowej, 2014). The above catalogue may raise doubts and reservations because the multitude and diversity of phenomena in the digital area defies such classifications. For instance, a blog can sometimes be treated as an example of the press, as understood by the Law on the press (Postanowienie S.A. Łódź, 2013).

If the publisher changes, while the title remains unaltered, the ISSN does not change. The ISSN National Centre needs to have the current issue submitted bearing the current masthead updated with the current details on the publisher. In the case of suspending or terminating publication, the ISSN National Centre should have the last issue submitted together with 
notice of its suspension or termination. In the case of changing the title of a continuing resource, its new title should be assigned a new ISSN code. For this purpose, an application for an ISSN code needs to be submitted, accompanied by the last issue of the old title and the first issue of the new title; if the issue with the new title has not yet been published, the design of its front page (including the number and date) and publisher page (including the masthead) should be submitted (Informacja Biblioteki Narodowej, 2014).

The issue of the legal form of the ISSN code assigned by the National Library raises doubts. Examining the current practice it should be unanimously concluded that these decisions do not meet the requirements of administrative decisions (Ustawa, 1960, Article 107, pgh 1 of the Code of Administrative Procedure). This matter is significant, inasmuch as the legal form of such a decision is of significance in view of potential prosecutions.

One more matter is worth remarking on, namely the phenomenon of special issues published on the press market. This term "special issues" is not defined by the Law on the press. The definition developed by the members of the Press Distribution Control Association (Zwiazek Kontroli Dystrybucji Prasy) for their purposes can be referred to here. In their understanding, a special issue is "such an issue of a controlled press title which is not a mutation and whose front page features all the markings required of a controlled press title, which in terms of its content, successive number and the date of issue (or the time of issue on a given day) is different than that of the controlled press title" (Regulamin, 2005). The same document indicates that "for the purpose of controlling the circulation and distribution of press, the special issue is treated as a separate press title" (Regulamin, 2005). This last provision is of no significance for assigning the ISSN code, however, since it concerns the verification of the size of the circulation of the publication.

It should also be remembered that Article 20, section 5 of the Law on the press makes it obligatory to immediately notify the registration body of any changes of details entered into the register of dailies and journals, that is the title, seat and exact address of the editor, personal details of the editor-in-chief, publisher and his seat and exact address as well as the frequency of publication. It is also emphasised in the legal literature on this topic that the latter concerns the declared rather than the actual publishing frequency (Sobczak, 1993, p. 47). Article 49 of the Law on the press stipulates that it is an intentional offence, punishable with a fine or detention, to infringe on certain provisions of the Law on the press, including Article 
27, which makes it obligatory to provide the publication with an impressum. The person accountable for the impressum is the editor-in-chief or another editor (for instance the editor of the issue) who shall bear the responsibility for the offence (Sobczak, 2008, p. 891). The regulation deems it an offence to fail to publish an impressum, as well as to publish an impressum with significant faults, outdated or false data as required by Article 27 of the Law on the press (Kosmus, Kuczyński, 2011, p. 588). It is also noted that since it is not obligatory to include an ISSN code in the impressum, failing to include it does not result in any liability, if only because of the negligible public harm caused (Kosmus, Kuczyński, 2011, p. 589), and does not lead to any other adverse legal consequences.

To conclude, the view can be supported that the use of the ISSN code is not obligatory, but recommended for the purpose of easier identification of the title and ensuring certainty about turnover. It can be stressed again that each title is assigned a unique, unrepeatable identification number. The identity of the periodical depends on its title, however, rather than the ISSN code which is only an auxiliary tool to identify the publication. The entry made in the register of dailies and journals is decisive in this respect. It should also be emphasised that the code is not conclusive when deciding about the right to the title and the more so about whether the publication of the periodical is legal.

\section{Bibliography}

Dobosz I. (2006), Prawo prasowe. Podręcznik, Warszawa 2006, p. 75.

Guidelines for ISDSm (1973) UNESCO SC/WS/538, Paris, May 1973, http://unesdoc.unesco.org/images/0000/000044/004470EB.pdf, 1.10.2014.

Informacja Biblioteki Narodowej (2014), Tryb uzyskania ISSN Wzór wniosku ISSN, http://www.bn.org.pl/programy-i-uslugi/issn/tryb-uzyskania-numeru-issn, 5.02.2014.

ISSN International Center, http://www.issn.org/the-centre-and-the-network/our-mission/ the-international-centre-for-the-registration-of-serial-publications-cieps/.

Kosmus B., Kuczyński G. (2011), Prawo prasowe. Komentarz, Warszawa.

List of the Member Countries of the ISSN, http://www.issn.org/wp-content/uploads/ 2014/06/LISTE-DES-PAYS-MEMBRES-JUIN-2014.pdf.

Michalski B. (1998), Podstawowe problemy prawa prasowego, Warszawa.

Nowińska E. (2008), Impressum, in: J. Barta, R. Markiewicz, A. Matlak, Prawo mediów, Warszawa. 
Polska Norma (2010) PN-ISO 3297:2010, Informacja i dokumentacja. Międzynarodowy znormalizowany numer wydawnictw ciagtych ISSN, Warszawa 2010.

Postanowienie (2002) Sądu Najwyższego z dnia 24 października 2002 r., I CKN 1344/2000, opublik. w LexPolonica no. 375471.

Postanowienie (2013) SA w Łodzi z 18.01.2013 r., sygn. akt: I ACa 1032/12.

Regulamin (2005) kontroli nakładu i dystrybucji prasy zarejestrowanej w Zwiazku Kontroli Dystrybucji Prasy (tekst jednolity obowiązujący od 1 stycznia 2005 r.).

Report (1970) on the Feasibility of an International Series Data System and Preliminary System Design, April 1970, DM/CB/284, http://unesdoc.unesco.org/images/0009/000985/098515eb.pdf, 1.10.2014.

Rozporządzenie (1990) Ministra Sprawiedliwości z dnia 9 lipca 1990 r. w sprawie rejestru dzienników i czasopism, Dz. U. 1990, Nr 46, poz. 275 z późn. zm.

Santiago S. (1993), International Series Data System, Col. 6, no. 1, March 1993, http://uksg.metapress.com/content/0akr6v4xpa4b0ybl/fulltext.pdf, 1.10.2014.

Skrzypczak J. (2011), Polityka medialna w okresie konwersji cyfrowej radiofonii i telewizji, Poznań.

Sobczak J. (1993), Polskie prawo prasowe, Poznań.

Sobczak J. (2008), Prawo prasowe. Komentarz, Warszawa.

UNESCO, International Series Data System (1973), Sc/UNISIST/St.Com. I, http://unesdoc.unesco.org/images/0000/000057/005789eb.pdf, 1.10.2014.

Ustawa (1960) z dnia 14 czerwca 1960 r., Kodeks postępowania administracyjnego, Dz. U. Nr 30, poz. 168 z późn. zm.

Ustawa (1984) z dnia 26 stycznia 1984 r. Prawo prasowe, Dz. U. No. 5, poz. 24 z późn. $\mathrm{zm}$.

Ustawa (1997) z dnia 27 czerwca 1997 r. ust. 1 pkt 5 o bibliotekach, Dz. U. 2012, poz. 642 z późn. zm.

Ustawa (2002) z dnia 12 września 2002 r. o normalizacji, Dz. U. Nr 169, poz. 1386 z późn. zm.

Wzór wniosku ISSN (2014), http://www.bn.org.pl/download/document/1373374474.pdf, 1.2.2014.

Zaremba M. (2007), Prawo prasowe. Ujęcie praktyczne, Warszawa.

\section{Międzynarodowy znormalizowany numer wydawnictw ciągłych (ISSN)}

\section{Streszczenie}

Przedmiotem o opracowania jest analiza roli i znaczenia numeru ISSN oraz międzynarodowych i krajowych reguł określających procedurę nadawania tego znaku. Powszechnie stosowany jest dziś na egzemplarzach wydawnictw prasowych jak również na ich elektronicznych wersjach, międzynarodowy znormalizowany numer 
wydawnictw ciagłych (ISSN). Potrzeba opracowania takiego uniwersalnego kodu identyfikującego tego typu wydawnictwa wynikała z konieczności zapewnienia pewności obrotu i wymiany pomiędzy wydawcami, dystrybutorami, bibliotekami, archiwami. Należy opowiedzieć się za poglądem, iż stosowanie ISSN nie jest obowiązkowe, aczkolwiek warto zalecać - z uwagi na możliwość łatwiejszego identyfikowania tytułu pisma a tym samym pewność obrotu - używanie tego znaku. Jeszcze raz należy podkreślić, że w ten sposób nadaje się jedynie niepowtarzalny, unikalny, przyporządkowany każdemu tytułowi numer identyfikacyjny. Dla tożsamości pisma decydujące znaczenie ma tytuł prasowy, a nie znak ISSN, który pełni rolę jedynie pomocniczą w zakresie identyfikacji czasopism. W tym zakresie, to odpowiedni wpis do rejestru dzienników i czasopism jest tu rozstrzygający. Natomiast trzeba podkreślić, że znak ten nie rozstrzyga w żadnej mierze o prawie do tytułu prasowego, a tym bardziej o tym, czy pismo ukazuje się legalnie. 
